\title{
de Garengeot hernia with a mucinous neoplasm of the appendix, two clinical rarities combine to yield a first for the literature
}

\author{
James William Ryan, ${ }^{1}$ Isobel O'Riordan, ${ }^{2}$ Tom Gorey, ${ }^{2}$ Tony Geoghegan ${ }^{1}$
}

${ }^{1}$ Department of Radiology, Mater Misericordiae University Hospital, Dublin, Ireland ${ }^{2}$ Department of Surgery, Mater Misericordiae University Hospital, Dublin, Ireland

Correspondence to Dr James William Ryan, jamesryannchd@gmail.com

Accepted 20 May 2017

\section{DESCRIPTION}

A woman in her 70 s presented for a scheduled CT scan for workup of an adnexal lesion. The adnexa were within normal limits; however, a blind-ending tubular structure was noted in the right femoral canal (figures 1 and 2). The diagnosis of a de Garengeot hernia was made. This is a rare type of hernia that occurs when the appendix descends to lie in the femoral canal. Femoral hernias comprise roughly $3 \%$ of all abdominal wall hernias, and de Garengeot hernias comprises $0.8 \%-1 \%$ of all femoral hernias. ${ }^{1}$

The patient was recalled for a surgical consultation. She had noticed a painless lump in her right groin over the preceding month. Her medical history was remarkable for hypertension and prior pulmonary tuberculosis. There was no surgical history. On examination, the patient's abdomen was soft and non-tender; there was a palpable lump in the right groin. Of note, the patient's laboratory results were

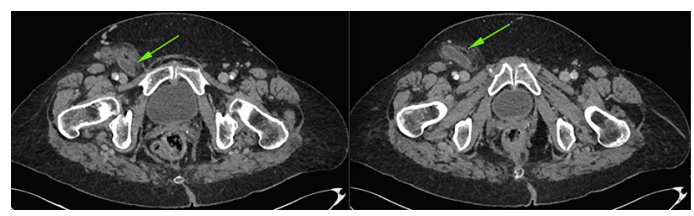

Figure 1 CT scan axial images. Green arrows: dilated appendix in the right femoral canal with prominent adjacent soft tissue stranding.

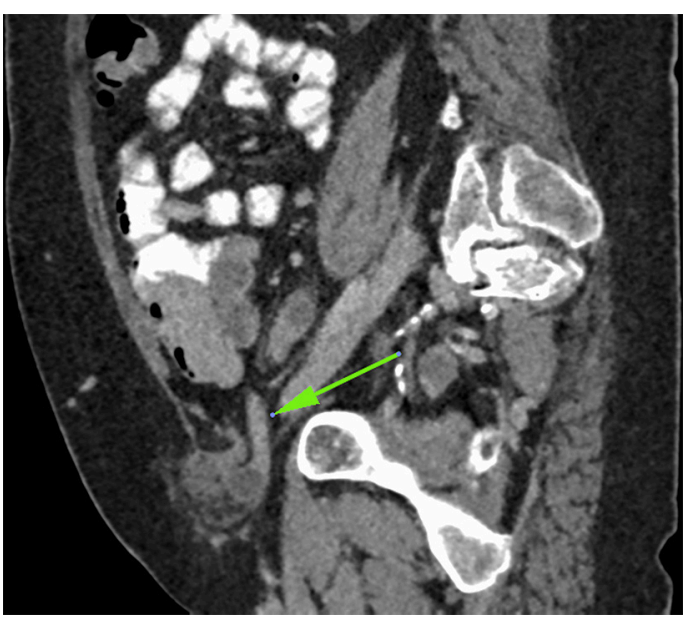

Figure 2 CT scan sagittal slice. Green arrow: normal proximal appendix transitioning into abnormal, dilated distal appendix on entering the femoral canal.

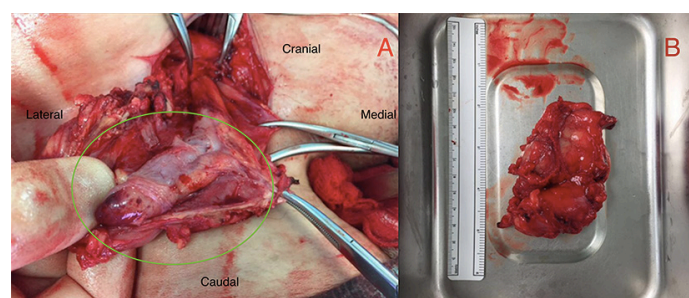

Figure 3 (A) Intraoperative image. Green circle: an engorged appendix with punctate haemorrhages at its distal tip. The appendix is protruding from an incision in the right groin. (B) Postappendectomy specimen.

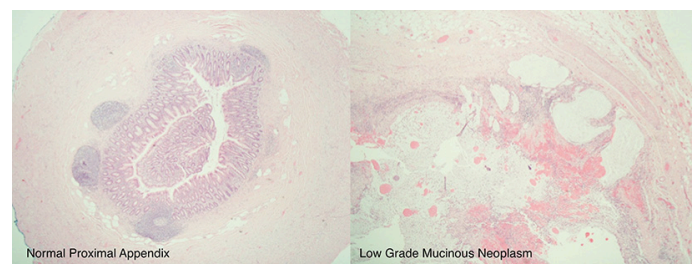

Figure 4 Histology sections demonstrating a normal proximal appendix and an abnormal distal appendix containing numerous mucinous pools extending to involve the submucosa in keeping with a low-grade mucinous neoplasm.

within normal limits, including white cell count, $C$ reactive protein and lactate.

An open appendectomy was performed through an oblique incision in the right groin (figure 3A). The appendix was engorged with punctate microhaemorrhages (figure $3 \mathrm{~A}, \mathrm{~B}$ ). Histological analysis revealed a low-grade mucinous neoplasm of the distal appendix (figure 4). Low-grade mucinous neoplasms have a prevalence of $<1 \%$ in appendectomy specimens. ${ }^{2}$ To

\section{Learning points}

- de Garengeot hernias are a very rare form of femoral hernia. ${ }^{1}$ While extremely rare, it should be kept in mind as part of the differential diagnosis for a right groin lump.

- de Garengeot hernias may be painful or completely asymptomatic as in this case, presenting as a painless groin lump. ${ }^{3}$

- CT and ultrasound may be used in order to make the diagnosis of a de Garengeot hernia. ${ }^{3}$ Histology is required to diagnose mucinous neoplasms. 
our knowledge, the combination of a de Garengeot hernia and a low-grade mucinous neoplasm has not been described previously in the literature. The patient had an uncomplicated postoperative course and was discharged 2 days later.

Contributors JWR is the first author and corresponding author. IOR gathered clinical details, took intraoperative photos and gained consent. TG is the caring surgeon for the patient, helped with provision of clinical data and intraoperative images. TGH is the senior author and reviewed manuscript prior to submission.

Competing interests None declared.

Patient consent Obtained.

Provenance and peer review Not commissioned; externally peer reviewed.
(C) BMJ Publishing Group Ltd (unless otherwise stated in the text of the article) 2017. All rights reserved. No commercial use is permitted unless otherwise expressly granted.

\section{REFERENCES}

1 Granvall SA. de Garengeot hernia: a unique surgical finding. JAAPA 2014;27:39-41

2 León Arellano M, González-Domínguez Y, Molina-Ortiz F, et al. Primary adenocarcinoma of the appendix: experience at La Paz University Hospital of Madrid (1967-2014). Int J Surg Open 2016;4:23-6.

3 Hao J, Yao J, Guo D, et al. De Garengeot hernia: the ultrasound and computed tomographic findings in an 81-year-old woman. Am J Emerg Med 2014;32:486. e5-486.e6.

Copyright 2017 BMJ Publishing Group. All rights reserved. For permission to reuse any of this content visit http://group.bmj.com/group/rights-licensing/permissions.

BMJ Case Report Fellows may re-use this article for personal use and teaching without any further permission.

Become a Fellow of BMJ Case Reports today and you can:

- Submit as many cases as you like

- Enjoy fast sympathetic peer review and rapid publication of accepted articles

- Access all the published articles

Re-use any of the published material for personal use and teaching without further permission

For information on Institutional Fellowships contact consortiasales@bmjgroup.com

Visit casereports.bmj.com for more articles like this and to become a Fellow 